University of North Florida

UNIVERSITY of

NORTH FLORIDA

UNF Digital Commons

History Faculty Publications

Department of History

3-2010

\title{
The NIDA Brain Disease Paradigm: History, Resistance and Spinoffs
}

David T. Courtwright

University of North Florida, dcourtwr@unf.edu

Follow this and additional works at: https://digitalcommons.unf.edu/ahis_facpub

Part of the History Commons

\section{Recommended Citation}

Courtwright, David T., "The NIDA Brain Disease Paradigm: History, Resistance and Spinoffs" (2010).

History Faculty Publications. 2.

https://digitalcommons.unf.edu/ahis_facpub/2

This Article is brought to you for free and open access by the Department of History at UNF Digital Commons. It has been accepted for inclusion in History Faculty

Publications by an authorized administrator of UNF Digital Commons. For more information, please contact Digital Projects.

(C) 3-2010 All Rights Reserved

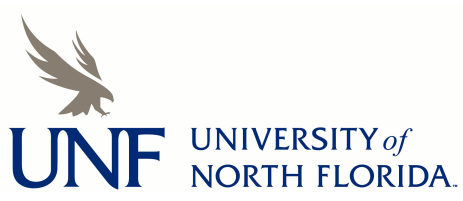




\title{
Original Article
}

\section{The NIDA brain disease paradigm: History, resistance and spinoffs}

\author{
David T. Courtwright \\ Department of History, University of North Florida, Jacksonville, Florida, 32224-2645, USA. \\ E-mail: dcourtwr@unf.edu \\ ${ }^{\dagger}$ The author has never applied for NIDA funding and has no conflicts of interest.
}

\begin{abstract}
This article examines 'the NIDA paradigm', the theory that addiction is a chronic, relapsing brain disease characterized by loss of control over drug taking. I critically review the official history of the National Institute on Drug Abuse (NIDA) paradigm and analyze the sources of resistance to it. I argue that, even though the theory remains contested, it has yielded important insights in other fields, including my own discipline of history.
\end{abstract}

BioSocieties (2010) 5, 137-147. doi:10.1057/biosoc.2009.3

Keywords: addiction; neuroscience; National Institute on Drug Abuse; drug policy; drug history; medicalization

\section{Introduction}

It is a commonplace in the history of science that new paradigms generate both opposition and unexpected insights. The National Institute on Drug Abuse (NIDA) paradigm of addiction as a brain disease has done both. The research behind it has expanded our knowledge of motivation and learning, of normal as well as abnormal behavior. Yet it has also been met with indifference, suspicion, and, in some cases, open resistance. I am particularly interested in why politicians, clinicians and social scientists have been slow to embrace what the neuroscientific community generally regards as a major breakthrough.

The key elements of the NIDA brain disease paradigm can be simply stated. They are that addiction is a chronic, relapsing brain disease with a social context, a genetic (or, more precisely, a gene-environment-stress-interactive) component, and significant comorbidity with other mental and physical disorders. Although drug use often begins voluntarily, and develops over time, users lose control with the onset of addiction. According to the former NIDA director, Alan Leshner, addiction is defined, not by physical withdrawal symptoms, but by 'uncontrollable, compulsive drug craving, seeking, and use, even in the face of negative health and social consequences'. Persistent use leads to long-term changes in brain structure and function. Neurons become more responsive to the biochemical changes triggered by drug consumption. Imaging studies have shown specific patterns of abnormal activity in the brains of many addicts. In essence, addiction is a brain disease because addicts exhibit a behavioral disorder that can be linked to observable pathological changes in their 
brains. To again quote Leshner, addiction is 'the quintessential biobehavioral disorder' (Leshner, 2001).

\section{History}

Where did this paradigm come from? Here is the official version, from the NIDA publication Drugs, Brains, and Behavior: The Science of Addiction. It bears the signature of Nora Volkow, the current NIDA director:

Throughout much of the last century, scientists studying drug abuse labored in the shadows of powerful myths and misconceptions about the nature of addiction. When science began to study addictive behavior in the 1930s, people addicted to drugs were thought to be morally flawed and lacking in willpower. Those views shaped society's responses to drug abuse, treating it as a moral failing rather than a health problem, which led to an emphasis on punitive rather than preventative and therapeutic actions. Today, thanks to science, our views and our responses to drug abuse have changed dramatically. Groundbreaking discoveries about the brain have revolutionized our understanding of drug addiction, enabling us to respond effectively to the problem. (National Institute on Drug Abuse, 2008, p. 1)

The statement evokes the Whiggish history of psychiatry. Substituting 'mental illness' for addiction gives a textbook account of beneficent medicalization. We used to treat mentally ill people as wicked or possessed, but now, thanks to neuroscience, we treat them as patients. The paradigm shift was progressive in another way. It tidied things up. Making the brain the affected organ, as historian Nancy Campbell has written, provided 'a unified framework for a problem-based field in conceptual disarray' and enabled addiction researchers to draw on the technical resources and social authority of neuroscience (Campbell, 2007, p. 200).

The political subtext of Volkow's statement is plain enough: keep funding our research. What may be less obvious is that virtually every historical claim in the statement is either factually incorrect or a form of wishful thinking. Let me start with the state of things before the 1930s, a decade presumably chosen because it corresponds to the opening of the federal narcotic hospitals and their research facilities. Neither popular nor medical opinion then regarded all addicts as morally flawed. People distinguished between medical cases and nonmedical addicts with underworld or delinquent backgrounds. All junkies were addicts, but not all addicts were junkies.

There was also a good deal of scientific investigation before the 1930s. Psychiatrist Lawrence Kolb, whom one colleague called 'the Osler of drug addiction', and who labored longer and harder than anyone to establish that addiction was a true mental disease, began his federally funded researches in 1923. These involved lab work with monkeys as well as the systematic study of 230 human cases (Kolb, 1962; Courtwright, 2001a, Chapter 5; Acker, 2002, Chapter 5). The relegation of Kolb's work to the dustbin of prescientific history may not have been entirely accidental. His primary finding, that nonmedical addiction was rooted in psychopathy and other preexisting (and hard-to-treat) personality disorders, fit 
poorly with the politics of medicalization and the NIDA paradigm's foundational metaphor, that drugs could flip the addiction 'switch' in even normal brains.

Ultimately, it may turn out that the tension between the personality and brain disease models is more apparent than real. Recent research has found that impulsive, thrill-seeking individuals have fewer D2 and D3 dopamine receptors in the ventral midbrain region, which means they have less inhibition of dopamine and experience more reward when stimulated by risky behavior (Sanders, 2008). The propensity to addiction and certain kinds of personality disorder may have genetic and/or epigenetic common denominators. This possibility also has been debated for a long time. Early twentieth-century researchers investigating cigarettes and health pondered whether the type of individual attracted to smoking might be as causally important in explaining the moral and physical harms of the habit as tobacco itself (Brandt, 2007, Chapter 4).

Other researchers - mostly asylum proprietors, psychiatrists and public-health physicians were thinking systematically about the nature of addiction even before Kolb began his work in the 1920s. What happened in the late twentieth century was essentially the confirmation and recasting of a series of shrewd hypotheses that these pioneers ventured. They held that alcohol, tobacco and other drug addictions were related through a common pathological action on the nervous system, which was permanently altered by the repeated use of drugs. Indeed, they often referred to nicotine and alcohol as 'narcotics' or 'deadly narcotics'. They believed that loss of control was the most important and troubling aspect of addiction. They knew how to get patients through withdrawal. The big challenge was how to prevent relapse. They postulated that some individuals were more vulnerable to addiction than others, whether through an inherited vulnerability or through an acquired, stress-related impairment of their nervous systems. In short, they believed that addiction was a chronic, recurrent nervous disease with both an environmental and hereditary component. What they lacked was the means to prove it (Courtwright, 2005).

The history of addiction as a brain disease looks a lot like the history of atoms or germs, insofar as these were all older and controversial ideas for which scientific confirmation later became available. Improved instrumentation and new laboratory techniques, together with the infusion of money and research talent into the field, made possible the fundamental discoveries in the second half of the twentieth century that served as the building blocks of the current NIDA paradigm. Among these were the observation of intracranial self-stimulation in rats; the discovery of an endogenous opioid system; the mapping of specific receptors and description of their functions; an understanding of drug sensitization and dendritic morphology; the piecing together of a mesolimbic dopamine reward pathway that was distinct from the anatomical pathways responsible for physical dependence and withdrawal syndromes; and, more recently, the location of single-nucleotide polymorphisms ('snips', or minute variations in DNA sequences) that seem to correlate with the risk of becoming an addict.

Dramatic improvements in neuroimaging also made possible the equivalent of Giovanni Morgagni's clinico-pathological studies. Morgagni pioneered the anatomical concept of disease. He based his classic 1761 study, De Sedibus et Causis Morborum, on some 700 case studies that showed how diseases with characteristic symptoms affected particular organs that exhibited characteristic lesions on postmortem examination. Imaging made it possible to show patterns of pre-mortem change on the primary organ that addiction afflicts, the brain. This idea is made explicit in Drugs, Brains, and Behavior, which juxtaposes positron 
emission tomography (PET) scans of a healthy and diseased heart with those of a healthy brain and the 'diseased brain' of a cocaine abuser. 'Addiction is similar to other diseases, such as heart disease', the caption explains. 'Both disrupt the normal, healthy functioning of the underlying organ, have serious harmful consequences, are preventable, treatable, and if left untreated, can last a lifetime' (National Institute on Drug Abuse, 2008, p. 5).

Some individuals do respond well to treatment. Yet the new paradigm has not led to a large increase in our ability to 'respond effectively to the problem', as Volkow claims. Here is the practical heart of the matter. The prevalence and incidence of drug abuse are largely determined by demographic variables like migration, family stability and birth cohort size, as well as social forces like drug-financed civil wars within failed states, pharmaceutical marketing strategies, bohemian fashion and generational learning (and forgetting) about the dangers of certain drugs. Pathological understanding is still disconnected from disease control, which is unusual in the history of medicine and public health. As psychiatrist Sally Satel puts it, a disease concept is not of much use unless it leads to 'actionable etiology' (Satel, 2009).

\section{Resistance}

Volkow makes another questionable claim. With the exception of medical marijuana and marijuana decriminalization initiatives in some states, there is little evidence that popular attitudes toward drug abuse have 'changed dramatically' in the United States in the recent past. Strikingly, federal policy toward illicit drugs became more, not less, punitive as the brain disease paradigm was solidifying in the 1980s and 1990s. Volkow's statement boils down to a claim about successful medicalization. But the drug-abuse field is characterized by, at best, incomplete and contested medicalization. As the French sociologist, Robert Castel, has observed, western medicine turned madness into a disease during the nineteenth century, and created institutions and therapies for managing it. But this has not happened for addiction, at least not to the same extent (Castel, 2008).

Instead, at least four important groups continue to wrestle for control of the addiction field. Medical personnel are concerned with addicts as patients. Police have a stake because addictive behavior often leads to crime and personal and social harms. Social scientists regard addiction as a social construction as well as a form of social behavior. Political actors, by which I mean organized interest groups as well as appointed officials and elected politicians, are in some ways the most important players, because they ultimately determine the details of drug control and addiction treatment policies.

One way to describe the modern history of US policy toward nonmedical drug use and addiction is to describe the varying fortunes of these four groups. Law enforcement dominated from the early 1920s to the mid-1960s, a period historians call 'the classic era of narcotic control' - classic in the sense of simple and rigid (Acker, 2002, p. 7). But, from the mid-1960s to the mid-1970s, medical and, to a lesser degree, social-scientific actors gained in influence. This was a time of promising new therapeutic approaches, methadone maintenance, the birth of NIDA, the efflorescence of drug ethnography, and a growing audience for the work of sociologists and historians who dissented from the official line. Yet the era of drug glasnost was brief. Law enforcement personnel regained their influence in the 
late 1970s and 1980s, even as NIDA was gathering the early fruits of the new scientific investigations. That raises an obvious question: why did the politicians not jump on the medicalization bandwagon? They were, after all, providing the funding that made the brain disease breakthrough possible.

The short answer is that American politicians had discovered an even more appealing bandwagon, that of selective reaction. What was being reacted against was the rise in crime, race riots, youthful drug experimentation, sexual permissiveness and liberal fecklessness broadly associated with the 1960s. Beginning with Ronald Reagan's successful run for the California governorship in 1966 and Richard Nixon's successful run for the presidency in 1968, appeals to popular illiberalism became an important part of Republican electoral strategy.

Yet Republicans faced a dilemma. They could run for office as social reactionaries, but they could not govern as social reactionaries, at least not across the board. No one was going to recriminalize abortion, bring back mandatory prayer in school, roll back civil rights, reimpose censorship and hang on to centrist voters. What they could and eventually did do was to selectively address backlash issues where a large majority, centrists included, demanded change. The three most important of these, all intertwined with race, class and gender, were criminal sentencing, welfare reform and the drug war.

Richard Nixon was the first Republican president to declare and fight a drug war, albeit one that initially combined novel medical and law enforcement approaches to the problem. The political appeal of a more narrowly punitive policy became apparent in January 1973 when New York governor and perennial presidential hopeful, Nelson Rockefeller, proposed mandatory life sentences for drug traffickers. Enough was enough, Rockefeller said. Polls showed that two-thirds of the state's residents agreed with him (Massing, 1998, pp. 126-128). Nixon immediately grasped the electoral logic of strict mandatory sentences. 'Rocky can ride the thing for all it's worth', he told his aides, Bob Haldeman and John Ehrlichman (Nixon, 1973). Three months later Nixon imitatively proposed his own increases in federal penalties for heroin trafficking.

The escalation of the Watergate scandal in the spring and summer of 1973 derailed Nixon's proposal, and much else in his domestic program. However, when Republicans returned to the White House in 1981, the drug issue still afforded excellent political opportunities. It gave First Lady Nancy Reagan the means to make over her image, and to ultimately win approval ratings higher than her popular husband's. It gave President Reagan the chance to deliver one of his most dramatic and popular speeches, the 14 September 1986 drug war declaration, which he made jointly with the first lady. It gave President George H. W. Bush the occasion for his first nationally televised address, in which he displayed a bag of crack seized near the White House. It gave drug czar, Bill Bennett, a bully pulpit and the opportunity to burnish his 'culture warrior' credentials. And it gave President George W. Bush, who approved annual drug control budget increases, another outlet for his big-stick, big-government conservatism.

What the drug war gave Democrats was mostly headaches. It contributed to the 1994 downfall of Surgeon General Jocelyn Elders who, among her other liberal sins, had suggested the possibility of studying drug legalization. It prevented President Bill Clinton from moving too fast to embrace medicalization or harm reduction for fear that he would be judged a weak drug warrior. For reasons of ideology and moral temperament, Democrats 
were (and remain) the party most open to medicalization. But Democratic politicians knew, from bitter experience, that they would pay a price for looking soft on drugs - just as Clinton understood that he would pay a price if he did not sign the 1996 welfare reform bill passed by a Republican Congress (Courtwright, forthcoming).

Beyond partisan calculation, there was a more subtle reason why NIDA officials failed to lure political actors away from the drug war. It was that their paradigm reinforced the logic of strict supply reduction. Like the sheet that has been dyed, the addicted brain could never become unaddicted. It was possible to learn to live with the new color, but the surest answer was prevention: keep the dye away from the sheet. As John D. Rockefeller Sr. liked to tell his Sunday school classes, you cannot become a drunkard if you never take your first drink (Chernow, 1998, p. 190). Harry Anslinger, longtime head of the Bureau of Narcotics, made a similar point about morphine and other medicinal narcotics. Why, Anslinger wanted to know, did doctors have rates of addiction that were so much higher than lawyers? Was it because doctors as a class were weaker or more sociopathic than lawyers? No, it was simply that doctors were exposed to drugs in a way that lawyers were not. At bottom, the rate of addiction was a function of availability. Controlling availability was therefore priority one (Maisel, 1945).

The same reasoning applied to cannabis or cocaine or any other addictive substance. The ultimate point of spraying illicit crops and hunting down traffickers and imposing prison terms was to reduce the prevalence of addiction and related problems like overdose and accidents. Tellingly, the Drug Enforcement Administration all but plagiarized NIDA's language to describe the long-term dangers of drugs like methamphetamine. Abuse could trigger addiction, 'a chronic, relapsing disease, characterized by compulsive drug-seeking and drug use which is accompanied by functional and molecular changes in the brain' (DEA, 2009). The flipped switch served as both a warning to the unwary and a policy trump card. Drug war critics could still criticize specific tactics as ineffectual or counterproductive or too costly. But, if the brain disease model was correct, and drug exposure led ineluctably to catastrophic addiction in a significant percentage of cases, the fundamental strategy of prosecution to reduce supply was hard to fault.

The usual rebuttal was that law enforcement efforts to reduce supply often backfired. Legal pressure in one place encouraged clandestine manufacturing in others, just as the disruption of existing trafficking routes encouraged smugglers to find alternatives. Sooner or later, illicit drugs began 'leaking out' wherever they were manufactured or transshipped. The result was more widespread abuse among previously low-use populations - as happened in Mexico, where the number of addicts reportedly doubled between 2002 and 2009 (Beith, 2009).

The surrebuttal was that drug use spread even faster when unregulated or poorly regulated, as evidenced by the many and far-flung drug epidemics of the nineteenth century. Concomitants or not, the principle of utility dictated that modern states punish those who sold dangerous drugs outside approved medical channels. More practically, the 'push-down, pop-up' effects of enforcement were often remote, a problem in someone else's backyard. What Republicans responded to in the 1970s and 1980s was growing pressure from organized and influential middle-class constituents to do something right now about the threat to their children. That the policy response got caught up in the current of competitive moral politics and overshot the falls of legislative reaction was in no way NIDA's doing. Yet, in hindsight, the agency's new science backed up the message of the old drug-frying-pan commercial: once your kid's brain plopped into sizzling neurotoxic grease, it stayed fried. 
The metaphor can be turned around: authorities do not ordinarily punish juvenile burn victims, even if they happened to be playing with matches. Although the brain disease paradigm offered aid and comfort to the supply-siders, it also furnished a moral argument to their opponents. If addiction was beyond the individual's control, then criminal punishment was as inappropriate as jailing a schizophrenic who wandered into an emergency room. 'The initial decision to take drugs is mostly voluntary', explains Drugs, Brains, and Behavior. 'However, when drug abuse takes over, a person's ability to exert self control becomes seriously impaired. Brain imaging studies from drug-addicted individuals show' - Morgagni again - 'physical changes in areas of the brain that are critical to judgment, decisionmaking [sic], learning and memory, and behavior control' (NIDA, 2008, p. 7).

Pathological loss of control has long been a fundamental consideration of medical ethics. Moreover, it seems unlikely that post-1973 US policy would have assumed such a punitive character if physicians had actively opposed it. Organized medicine was hardly without political influence. It had successfully exercised that influence on other occasions notably in opposition to national health insurance - to block legislation that commanded widespread support. If it was becoming clear in the 1980s and 1990s that addiction really was a brain disease, why did the medical profession and its allies fail to put up much of a fight against the prison-oriented drug war? Why, for that matter, are they still largely acquiescent?

The most obvious answer is that the brain disease model has so far failed to yield much practical therapeutic value. Clinicians have acquired some drugs, such as Wellbutrin and Chantix for smokers, Campral for alcoholics or buprenorphine for heroin addicts, but no magic bullets. Stuck in therapeutic limbo, with pathological insight but little ability to cure the underlying pathology, they have had no routine clinical alternative to the dominant supply-side approaches.

Counterfactually, if the brain disease model ever yields a pharmacotherapy that curbs craving, or a vaccine that blocks drug euphoria, as some researchers hope (Condon, 2006), we should expect the rapid medicalization of the field. Under those dramatically costeffective circumstances, politicians and police would be more willing to surrender authority to physicians. Even if they were not so disposed, the fiscal burden of mass imprisonment has reached the point where voters might force them to do so. Pharmaceutical companies would also have a financial interest in using any therapeutic discoveries to medicalize addiction, as they have with Viagra and 'erectile dysfunction', human growth hormone and 'idiopathic short stature', and Paxil and shyness, rechristened 'social anxiety disorder' (Conrad, 2007).

Another reason for clinicians' acceptance of the status quo was that the drug war, for all its excesses, never seriously endangered their ability to prescribe mood-altering drugs. Richard DeGrandpre has criticized the division of the pharmacopeia into nonmedical 'devil' drugs and medical 'angel' drugs. The latter, he argues, were protected and privileged by pharmaceutical interests, bureaucrats and medical researchers, including the NIDA brain disease establishment. Whether or not current drug scheduling is actually irrational (or, for that matter, dichotomous), it has never been so aggressive that organized medicine felt it had to revolt. On the contrary, many critics think that prescribing remains underregulated. Doctors, abetted by big-name researchers in the pay of pharmaceutical companies, have been prescribing far too many unproven and dangerous psychoactive drugs for far too many patients, including young children (DeGrandpre, 2006; Angell, 2009). 
Finally, why were social scientists slow to embrace the NIDA paradigm? Some of them, like psychologists Stanton Peele (1998) and Bruce Alexander (2008), simply thought it was wrong on its merits, that it was reductively inattentive to individual values and social context. DeGrandpre has similarly argued that it is set and setting that matter, not just neurons pickled in a sea of exogenous toxins. Beyond that, there were strong disciplinary biases at work. Social scientists have long been collectively suspicious of anything that smacks of biological essentialism. Biological explanations, after all, have a notorious dark side, having been used to stigmatize, exploit and exterminate minority groups. On one level, social-scientific skepticism about the NIDA paradigm was part of a broader post-World War II pattern of resistance against biological explanations of behavior, genetic research and the neo-Darwinian renaissance (Degler, 1991).

Although that resistance has recently shown signs of abating, it is still very much in evidence among social science's old guard. Troy Duster, an influential sociologist who has written on drugs, deviance, race and science, highlighted the concern in his 2005 presidential address to the American Sociological Association. He spoke frankly of the challenge of scientific authority and 'the attendant expansion of data bases on markers and processes "inside the body". For Duster, reductionist science was the enemy at the gates, threatening to further defund and marginalize sociology, draw attention from the decisive social and economic forces, and dominate the policy process (Duster, 2006, p. 1).

Another way to say this is that both social scientists and neuroscientists still live in their own gated academic communities, that they engage in vigorous boundary maintenance, and that they champion their own disciplinary and subdisciplinary master variables. There is a lot more at stake in the brain disease debate than our understanding of addiction. At bottom, it is really a high-stakes argument about how we ought to understand human behavior, motivation and pleasure - and about what policies we should adopt to regulate it.

\section{Spinoffs}

Yet such academic resistance in no way implies the failure of the brain disease theory. All new scientific paradigms encounter opposition, much of it socially or politically motivated. Paradigms that can both explain familiar problems and unresolved puzzles usually win out in the end, assuming the mantle of the new 'normal science' (Kuhn, 1970).

One of the NIDA paradigm's strengths has been its ability to shed light on fundamental research questions in other fields, such as the neuronal basis of learning and memory, or the nature of behavioral addictions. Researchers have shown that reward cues 'light up' the same neural pathways in behavioral and drug addictions, and that opiate antagonists like Naltrexone have value in treating disorders like compulsive gambling (Vrecko, 2010). These striking findings legitimate the idea that some people with bad habits are genuinely addicted. They also reinforce the NIDA paradigm. Scientists favor theories that prove to be both parsimonious and unifying, such as Darwinian evolution. In fact, the NIDA paradigm extends evolutionary theory. Michael Kuhar has argued that, because the brain co-evolved with neurotransmitters, it can usually manage its internal chemistry quite well. But it did not co-evolve with drugs, understood as recently introduced and wholly exogenous superneurotransmitters that can override the brain's control mechanisms. Drugs can stimulate 
reward neurons for minutes or hours instead of the usual milliseconds before reuptake. No wonder drugs and their cues make such a lasting impression on the memory, or have such potential to impair judgment (Kuhar, 2010).

This brings me to my own research. Whatever defects I may have identified in its official history, I count myself among the beneficiaries of the NIDA paradigm. It guided me when I wrote Forces of Habit, a study of the spread and commercialization of the planet's psychoactive resources. I noticed that the most commercially popular drugs invariably affected, whether strongly or weakly, directly or indirectly, the reward system that neuroscientists now held to be central to both motivation and craving. That could not be a coincidence. Dopamine reward helped explain why an exotic, bizarrely consumed, seemingly diabolical drug like tobacco, which often met with fierce official resistance, caught on wherever it was introduced in the early modern world. Dopamine reward also helped explain why exposure mattered so much, and why proximity to supply was by far the most important variable for explaining addiction rates in different countries.

Research on the ways drugs synergistically increased dopamine levels helped me understand why novel combination practices, like smoking tobacco while drinking spirits, had taken root together. The permanent alteration of neurons and the development of addiction in some, but not all, users also helped explain the commercial and tax appeal of drugs, insofar as they were nondurable goods with relatively inflexible demand curves. Even non-addicted users tended to consume more over time, because of tolerance (Courtwright, 2001 b, Chapter 5). Of course, biology was not the whole story. Social influences, as when young people smoked in imitation of adults, also played important roles. But the larger point remains. Someone in an unrelated discipline, history, was able to draw on NIDA-sponsored research to gain insight and solve puzzles.

This suggests one final analogy. The NIDA paradigm and the neuroscience behind it may yet prove to be a scaled-down version of the manned space program. Even though NASA failed to achieve its central long-term objective - cheap, routine and dependable human access to space - it nevertheless demonstrated the possibility of travel beyond the atmosphere and produced any number of 'spinoffs'. Among those claimed by NASA were programmable heart pacemakers, waste purification, solar energy, cordless appliances, laser surgery, liquid crystal displays, epoxy adhesives, portable computers, parallel processing and digital body imaging - the last, of course, a key tool for NIDA researchers (National Aeronautics and Space Administration, 1992). Although it is too soon to pronounce judgment, it seems possible that NIDA's own brain disease research will follow a similar trajectory. That is, it can fail in its central political objective - the medicalization of a treatable disease - and yet still succeed in winning scientific converts and sparking innovations in other fields. It would not, after all, be the first time that policy and science went their separate ways.

\section{About the Author}

David Courtwright has written about the history of drug use and drug policy in such books as Addicts Who Survived (1989), Dark Paradise: A History of Opiate Addiction in America 
(2001) and Forces of Habit: Drugs and the Making of the Modern World (2001). He is currently Presidential Professor in the Department of History at the University of North Florida.

\section{References}

Acker, C.J. (2002) Creating the American Junkie: Addiction Research in the Classic Era of Narcotic Control. Baltimore, MD: Johns Hopkins University Press.

Alexander, B. (2008) The Globalization of Addiction: A Study in Poverty of the Spirit. New York: Oxford University Press.

Angell, M. (2009) Drug companies and doctors: A story of corruption. New York Review of Books 56(15 January): 8-12.

Beith, M. (2009) Mexico needs an intervention. Newsweek 154(10 August/17 August): 8.

Brandt, A.M. (2007) The Cigarette Century: The Rise, Fall, and Deadly Persistence of the Product that Defined America. New York: Basic Books.

Campbell, N.D. (2007) Discovering Addiction: The Science and Politics of Substance Abuse Research. Ann Arbor, MI: University of Michigan Press.

Castel, R. (2008) Closing remarks, International Conference on Drugs and Culture, Sciences Po, Paris, 13 December.

Chernow, R. (1998) Titan: The Life of John D. Rockefeller, Sr. New York: Random House.

Condon, T.P. (2006) Reflecting on 30 years of research: A look at how NIDA has advanced the research, prevention, and treatment of drug abuse and addiction. Behavioral Healthcare 26(May): 14-16.

Conrad, P. (2007) The Medicalization of Society: On the Transformation of Human Conditions into Treatable Disorders. Baltimore, MD: Johns Hopkins University Press.

Courtwright, D.T. (2001a) Dark Paradise: A History of Opiate Addiction in America. Cambridge, MA: Harvard University Press.

Courtwright, D.T. (2001b) Forces of Habit: Drugs and the Making of the Modern World. Cambridge, MA: Harvard University Press.

Courtwright, D.T. (forthcoming, title tentative) The Illusion of Conservatism. Cambridge, MA: Harvard University Press, in press.

Courtwright, D.T. (2005) Mr ATOD's wild ride: What do alcohol, tobacco, and other drugs have in common? Social History of Alcohol and Drugs 20: 105-140.

Degler, C.N. (1991) In Search of Human Nature: The Decline and Revival of Darwinism in American Social Thought. New York: Oxford University Press.

DeGrandpre, R. (2006) The Cult of Pharmacology: How America Became the World's Most Troubled Drug Culture. Durham, NC: Duke University Press.

Drug Enforcement Administration. (2009) Methamphetamine, http://www.usdoj.gov/dea/concern/meth .html.

Duster, T. (2006) Comparative perspectives and competing explanations: Taking on the newly configured reductionist challenge to sociology. American Sociological Review 71: 1-15.

Kolb, L. (1962) Drug Addiction: A Medical Problem. Springfield, IL: Charles C. Thomas.

Kuhar, M. (2010) Contributions of basic science to understanding addiction. BioSocieties 5(1): 25-35.

Kuhn, T.S. (1970) The Structure of Scientific Revolutions, 2nd edn. Chicago, IL: The University of Chicago Press.

Leshner, A.I. (2001) Addiction is a brain disease. Issues in Science and Technology Online, http:// www.issues.org/17.3/leshner.htm.

Maisel, A.Q. (1945) Getting the drop on dope. Liberty (24 November), unpaginated reprint, 'US Bureau of Narcotics - History', vertical files, DEA Library, Arlington, VA.

Massing, M. (1998) The Fix. New York: Simon and Schuster.

National Aeronautics and Space Administration. (1992) NASA Spinoffs: 30 Year Commemorative Edition. Washington DC: NASA Technology Transfer Division.

National Institute on Drug Abuse. (2008) Drugs, Brains, and Behavior: The Science of Addiction, revised edn. Washington DC: National Institute on Drug Abuse. 
Nixon, R. (1973) Tape 393-11B, Nixon Presidential Library and Museum, http://www.nixonlibrary.gov/ forresearchers/find/tapes/tape393/tape393.php.

Peele, S. (1998) The Meaning of Addiction: An Unconventional View. San Francisco, CA: Jossey-Bass.

Sanders, L. (2008) Fewer dopamine receptors makes for risky business. Science News, 30 December.

Satel, S. (2009) The addicted patient. Presentation at Addiction, the Brain, and Society, Emory University, February 2009.

Vrecko, S. (2010) 'Civilizing technologies' and the control of deviance. BioSocieties 5(1): 36-51. 